\title{
SERIES OF COVID-19 OUTBREAKS IN SEVERAL SETTLEMENTS OF MANGISTAU REGION OF THE REPUBLIC OF KAZAKHSTAN
}

\author{
Marat S SYZDYKOV ${ }^{1}$, Lyudmila V BYURABEKOVA ${ }^{2}$, \\ Nurkan O SADVAKASOV ${ }^{2}$, \\ Andrey N KUZNETSOV ${ }^{1}$, https://orcid.org/0000-000-2354-533X, \\ Toktasyn K YERUBAYEV ${ }^{1}$, https://orcid.org/ 0000-0001-8894-3326, \\ Svetlana F DAULBAYEVA ${ }^{3}$, Arman S KUSSAINOVA ${ }^{3}$
}

${ }^{1}$ Aykimbayev National Scientific Center for Especially Dangerous Infections, Health Ministry, Almaty, Republic of Kazakhstan, ${ }^{2}$ Ministry of Healthcare of the Republic of Kazakhstan, Nur-Sultan,

${ }^{3}$ Kazakhstan-Russian Medical University, Almaty, Republic of Kazakhstan

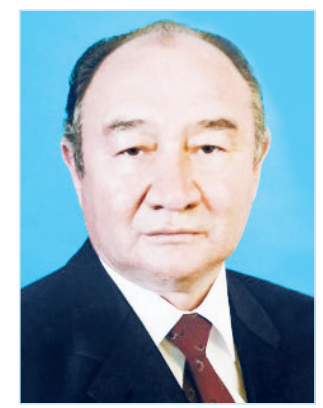

Syzdykov MS

COVID-19 is a severe disease, which mainly affects respiratory system and causes lung failure. The disease spread dramatically over the world, including Kazakhstan. Between March 13 and September 30,2020 , a total of 107,979 laboratory confirmed cases of COVID-19 were registered in the republic.

The aim of the study was to describe the epidemiological characteristics of COVID-19 outbreaks in five localities of Beyneu and Karakiya districts of Mangistau region of the Republic of Kazakhstan.

Methods. A descriptive cross-sectional study was carried out in Mangistau region for the period from 31 May 2020 till 06 June 2020 to investigate the epidemiological characteristics of several COVID-19 outbreaks, and to assess the effectiveness of implemented intervention.

Results. In the Mangistau region, in the oil production area, five outbreaks of COVID-19 were registered: two in the Beyneu region (Beyneu settlement and Borankul village), one in the Karakiyan region (Senek village) and two at the Kalamkas and Zhetibay oil fields, where there were foci with the number of cases from two to 100 cases.

Discussion. The main reason for the spread of the disease was overcrowding and cross-contact between oilfield workers, which influenced the registration of outbreaks among workers in field camps. The active movement of workers between camps, the involvement of medical workers with no experience in using PPE to work at checkpoints and local hospitals, as well as the presence of a confirmed case of COVID-19 at funerals where participants did not use respiratory protection also influenced the spread of infection.

Conclusions. This article describes the epidemiologic features of the outbreak series in five settlements located in the oil production zone of Mangistau region of Kazakhstan during May - June of 2020. An exponential increase in numbers of COVID-19 patients in Beyneu district appeared to be caused by exposure among the members of in canteens and dormitories for shift workers in oil-producing areas with the additional community- and hospital-transmission.

Keywords: COVID-19, outbreaks, Kazakhstan.

For reference: Syzdykov MS, Byurabekova LV, Sadvakasov NO, Kuznetsov AN, Yerubayev TK, Daulbayeva SF, Kussainova AS. Series of COVID-19 outbreaks in several settlements of Mangistau region of the Republic of Kazakhstan. Meditsina (Almaty) = Medicine (Almaty). 2020;7-8(217-218): 8-12 (In Russ.). DOI: 10.31082/1728-452X-2020-217-218-7-8-8-12

Contacts: Kuznetsov Andrey Nikolaevich - Head of the Department of Biological Safety and Biological Protection of Aykimbayev National Scientific Center for Especially Dangerous Infections, Almaty, e-mail: dr.a.n.kuznetsov@gmail.com

Контакты: Кузнецов Андрей Николаевич - начальник Отдела биологической безопасности и биологической защиты Национального научного центра особо опасных инфекций им. М. Айкимбаева, г. Алматы, e-mail: dr.a.n.kuznetsov@gmail. com

Поступила: 28.10.2020

\section{Т ¥ жыр Ы M}

\section{ҚАЗАҚСТАННЫҢ МАҢҒЫСТАУ ОБЛЫСЫНЫҢ БІРНЕШЕ ЕЛД МЕКЕНІНДЕ COVID-19 IНДЕТІНІҢ ӨРШУ СЕРИЯСЫ}

\author{
Марат С. СЫзДЫқОВ 1 , Людмила В. БЮРАБЕКОВА², \\ Нұрқан О. СәДУАҚАСОВ², \\ Андрей Н. КУЗНЕЦОВ ${ }^{1}$, https://orcid.org/0000-000-2354-533Х, \\ Тоқтасын К. ЕРУБАЕВ', https://orcid.org/0000-0001-8894-3326, \\ Светлана Ф. ДАУЫЛБАЕВА ${ }^{3}$, Арман С. ҚҰСАЙЫНОВА ${ }^{3}$
}
1"М. Айқымбаев атындағы аса қауіпті инфекциялар Ұлттық ғылыми орталығы" ШЖҚ РМК, Алматы қ., Қазақстан Республикасы,
${ }^{2}$ Қазақстан Республикасы Денсаулық сақтау министрлігі,Нұр-Сұлтан қ.,
${ }^{3}$ «Қазақстандық-Ресейлік медицина университеті», Алматы қ., Қазақстан Республикасы
COVID-19 - бұл негізінен тыныс алу жүйесін зақымдайтын және өкпе жеткіліксіздігін тудыратын ауыр ауру. Ауру әлемде, соның ішінде Қазақстанда да кең таралды. 2020 жылғы 13 наурыздан 30 қы-

Reviewers: Egemberdieva Ravilya Aitmagambetovna, Doctor of Medical Sciences, Professor of the Department of Infectious and Tropical Diseases, Asfendiyarov KazNMU, Almaty, e-mail: regemberdieva@rambler.ru

Knaus Anna Aleksandrovna, Candidate of Medical Sciences, Associate Professor of the Department of Infectious Diseases and Dermatovenereology, Karaganda Medical University, Karaganda, e-mail: dr.knaus@mail.ru 
ркүйекке дейін Республикада COVID-19 індетінің 107979 зертханалық расталған жағдайы тіркелген.

Зерттеудің мақсаты Қазақстанның Маңғыстау облысы Бейнеу ауданының бес елді мекеніндегі COVID-19 індетінің эпидемиологиялық сипаттамаларын беру болды.

Әдістер. 2020 жылдың 31 мамыры мен 2020 жылдың 6 маусымы аралығында Маңғыстау облысында бірнеше COVID-19 өршу жағдайының эпидемиологиялық сипаттамаларын зерттеу және жүргізілген іс-шаралардың тиімділігін бағалау үшін сипаттамалық айқас-зерттеу жүргізілді.

Алынған нәтижелері. Маңғыстау облысында, мұнай өндіру аумағында COVID-19 бес өршу жағдайы тіркелді: екеуі Бейнеу ауданында (Бейнеу кенті және Боранқұл ауылы), біреуі Қарақия ауданында (Сенек ауылы), екеуі екеуі "Қаламқас" және "Жетібай" мұнай кен орындарында, бұнда екіден 100 жағдайға дейін ауру ошақтары болды.

Талқылауы. Аурудың таралуының негізгі себебі мұнай кен орны қызметкерлерінің көптеп әрі тығыз жиналуы болған, бұл кен орнының вахталық қалашықтарының қызметкерлері арасында өршу жағдайының тіркелуіне әсер етті. Сондай-ақ, инфекцияның таралуына вахталық кенттер арасында қызметкерлердің белсенді қозғалысы, блок-бекеттерде және жергілікті госпитальдарда жұмыс істеу үшін ЖҚҚ пайдалану тәжірибесі жоқ медицина қызметкерлерін тарту, сондай-ақ қатысушылар тыныс алу органдарын қорғау құралдарын пайдаланбаған жерлеуде COVID-19 расталған жағдайының болуы әсер етті.

Қорытынды. Осы мақалада 2020 жылғы мамыр-маусым аралығындағы кезеңде Қазақстанның Маңғыстау облысының мұнай өндіру аймағында орналасқан бес елді мекенде өршу сериясының эпидемиологиялық ерекшеліктері сипатталады. Бейнеу ауданындағы COVID-19 науқастарының экспоненциалды артуына мұнай өндіретін аудандардың асханалары мен жатақханаларда вахтамен істейтіндердің науқастануы және қосымша түрде инфекцияның жергілікті тұрғындар мен ауруханаларда таралуы әсер еткен секілді.

Негізгі сөздер: COVID-19, өршу, Қазақстан.

\title{
P E 3 Ю M E
}

\section{СЕРИЯ ВСПЫШЕК COVID-19 В НЕСКОЛЬКИХ НАСЕЛЁННЫХ ПУНКТАХ МАНГИСТАУСКОЙ ОБЛАСТИ КАЗАХСТАНА}

\author{
Марат С. СЫЗДЫКОВ 1 , Людмила В. БЮРАБЕКОВА², \\ Нуркан О. САДВАКАСОВ ${ }^{2}$, \\ Андрей Н. КУЗНЕЦОВ 1 , https://orcid.org/0000-000--2354-533Х, \\ Токтасын К. ЕРУБАЕВ', https://orcid.org/ 0000-0001-8894-3326, \\ Светлана Ф. ДАУЛБАЕВА ${ }^{3}$, Арман С. КУСАИНОВА $^{3}$
}

${ }^{1}$ РГП на ПХВ «Национальный научный центр особо опасных инфекций имени М. Айкимбаева», 2. Алматы, Республика Казахстан,

${ }^{2}$ Министерство здравоохранения РК, г. Нур-Султан, Республика Казахстан, ${ }^{3}$ НУО «Казахстанско-Российский медицинский университет»,

г. Алматы, Республика Казахстан

COVID-19 - тяжёлое заболевание, которое в основном поражает дыхательную систему и вызывает лёгочную недостаточность. Заболевание широко распространилось в мире, включая Казахстан. С 13 марта по 30 сентября 2020 года в республике зарегистрировано 107979 лабораторно подтверждённых случаев COVID-19.

Целью исследования было описание эпидемиологических характеристик вспышек COVID-19 в пяти населённых пунктах Бейнеуского района Мангистауской области Казахстана.

Методы. Описательное перекрёстное исследование было проведено в Мангистауской области в период с 31 мая 2020 года по 6 июня 2020 года для изучения эпидемиологических характеристик нескольких вспышек COVID-19 и оценки эффеективности проведённых мероприятий.

Полученные результаты. В Мангистауской области, в районе нефтедобычи, зарегистрированы пять вспышек COVID-19: две в Бейнеуском районе (посёлок Бейнеу и село Боранкул), одна в Каракиянском районе (село Сенек) и две на нефтяных месторождениях «Каламкас» и «Жетибай», где имелись очаги с числом заболевших от двух до 100 случаев.

Обсуждение. Основной причиной распространения заболеваемости явились скученность и перекрёстное контактирование между работниками нефтяного месторождения, что повлияло на регистрацию вспышек среди работников вахтовых городков месторождения. Также повлияли на распространение инфекции активное перемещение работников между вахтовыми посёлками, привлечение медицинских работников, не имеющих опыта использования СИЗ, для работы на блок-постах и местных госпиталях, а также присутствие подтверждённого случая COVID-19 на похоронах, где участники не использовали средства защиты органов дыхания.

Выводы. В данной статье описываются эпидемиологические особенности серии вспышек в пяти населённых пунктах, расположенных в зоне нефтедобычи Мангистауской области Казахстана в период с мая по июнь 2020 года. Экспоненциальный рост числа больных COVID-19 в Бейнеуском районе, по всей видимости, был вызван заражением в столовых и общежитиях 
для вахтовиков в нефтедобывающих районах с дополнительной передачей среди местных жителей и в больницах.

Ключевые слова: COVID-19, вспышки, Казахстан.

Для цитирования: Сыздыков М.С., Бюрабекова Л.В., Садвакасов Н.О., Кузнецов А.Н., Ерубаев T.K., Даулбаева С.Ф., Кусаинова А.С. Серия вспышек COVID-19 в нескольких населённых пунктах Мангистауской области Казахстана // Медицина (Алматы). - 2020. - №7-8 (217-218). C. 8-12. DOI: 10.31082/1728-452X-2020-217-218-7-8-8-12

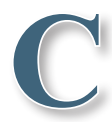
OVID-19 is a severe disease, which mainly affects respiratory system and causes lung failure [1]. The etiological agent of COVID-19 has been confirmed as a novel coronavirus, now known as severe acute respiratory syndrome coronavirus 2 (SARS-CoV-2), which is most likely originated from zoonotic coronaviruses, like SARS-CoV, which emerged in 2002 [2]. The virus belongs to the order Nidovirales, family Coronaviridae, subfamily Orthocoronavirinae, the subgenus Sarbecovirus of the genus Betacoronavirus [3]. The global incidence of COVID-19 has increased dramatically: by April 2020 it has affected 85,403 patients in 57 countries/territories and has caused 2,924 deaths in 9 countries [4]. So, national healthcare systems are facing the contagion with the need of immediate emergency response.

The first cases of COVID-19 in Kazakhstan were registered on March 13, 2020 in the cities of Almaty and Nur-Sultan. These cases were imported from Germany and Italy [5]. From March 20, confirmed cases of COVID-2019 began to be registered in other regions of the country [5]. The vast majority of symptomatic patients had mild disease, and the proportion of patients with moderate disease was about 10\% [6]. Between March 13 and September 30, 2020, a total of 107,979 laboratory confirmed cases of COVID-19 were registered in Kazakhstan. Of them $8,518(7.8 \%)$ cases occurred in healthcare workers (own data).

This study aims to describe epidemiological characteristics of the COVID-19 outbreaks in five settlements of Beyneu and Karakiya districts of Mangistau region of the Republic of Kazakhstan.

\section{METHODS}

Study design
A descriptive cross-sectional study was carried out in Mangistau region for the period from 31 May 2020 till 06 June 2020 to investigate the epidemiological characteristics of several COVID-19 outbreaks, and to assess the effectiveness of intervention implemented.

\section{Case definition and case-finding}

Case-finding and field epidemiological investigation was conducted among all households in the target area; we used diagnostic criteria and case definitions for COVID-19 from the National Clinical Protocol, 7th edition, that corresponds to the WHO case definitions of 27 February 2020.

\section{STUDY SITE}

Mangistau region (province) is located in the south-west of Kazakhstan, to the east of the Caspian Sea on the Mangyshlak plateau (Mangistau). The administrative center is the city of Aktau, an international seaport. Mangistau region is an industrial region, 25\% of Kazakhstan's oil is produced here. There are seven administrative territories in the oblast: two cities, five rayons (districts). The population of Mangistau region as of 01 January 2020 is 707,329 people, including 247,446 children under 14 years old.

\section{RESULTS}

As of June 4, 343 cases of COVID-19 were recorded in Mangistau region (cumulative incidence was 48.5 per 100,000 population). In two rayons of the region, a high incidence level of COVID-19 was observed: in Karakiyanskiy districts it was 138.0, and in Beyneuskiy districts it was 190.3, which exceeds the regional level by $2.8-4.0$ times, respectively (Figure 1).

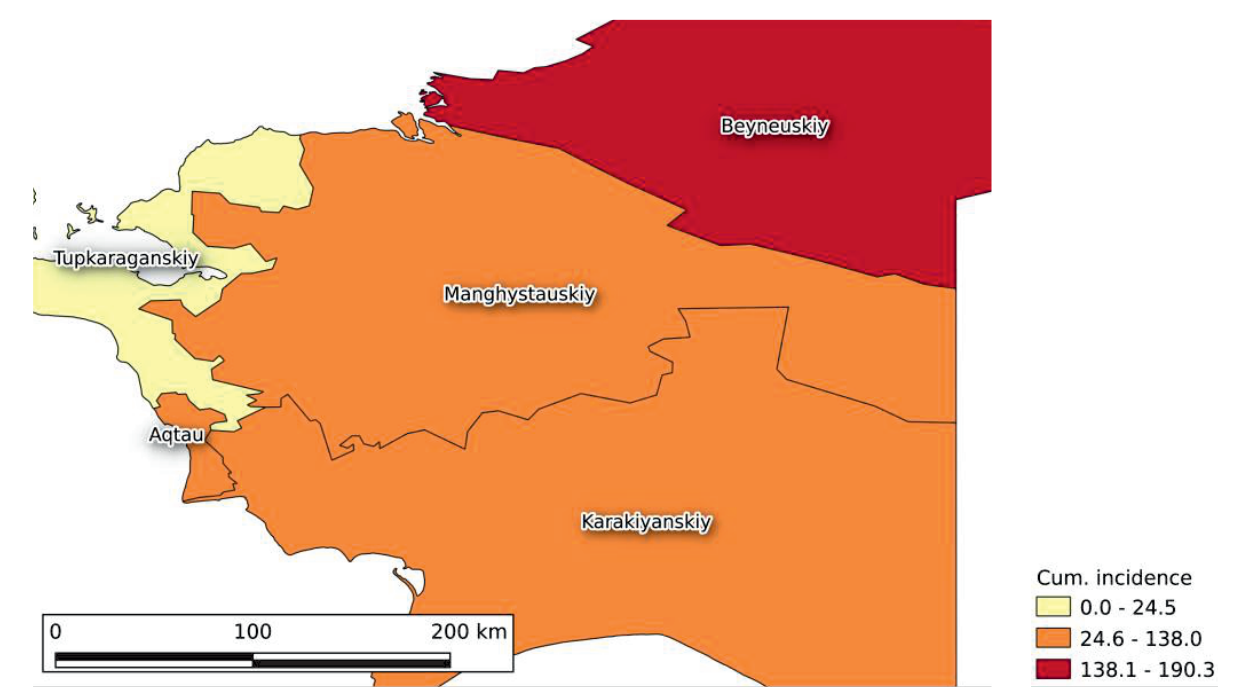

Figure 1 - COVID-19 cumulative incidence levels in districts of Mangistau region 
The mean age of cases was $49.0 \pm 19.2 \mathrm{SD}$. The main risk groups for COVID-19 were non-working people (16.9\%), workers of Tenigizchevroil Company (TCO; $10.2 \%$ ), including catering staff $(2.3 \%)$, medical workers $(10.5 \%)$ and retirees $(7.3 \%)$. All identified catering workers were employees of the Caspian Food Company and were located at the TCO Company's Kalamkas oil field at the time the COVID-19 outbreak began (Table 1).

Analysis of a COVID-19 daily timeline in Mangistau region shown that there were two incidence increases: from April 29 to May 17, 2020 and from May 28 to June 4, 2020 (Figure 2).

The COVID-19 incidence increase in the period from April 29 to May 17, 2020 was due to residents of the village of Senek and the town of Zhanaozen had contact with a previously identified COVID-19 patient in the village of Senek, Karakiyanskiy districts, during the funeral with the Muslim ritual of Sadaqah that led to mass people contamination.

The incidence increase in the period from May 28 to June 4, 2020 was associated with the identification of COVID-19 cases at the Kalamkas and Zhetybai oil fields. In the same period there were COVID-19 outbreaks in the villages of Beyneu and Borankul.

Thus, from April to June, five outbreaks were detected in Mangistau region: in Beineuskiy rayon (villages of Beineu and Borankul), in Karakiyansky rayon (village of Senek) and in the oil fields Kalamkas and Zhetibay.

Description of the outbreaks is given below.

Outbreak 1. Senek village (April 27-29, Karakiyanskiy districts)

The first two cases of coronavirus infection were reported on April 27, 2020. As mentioned above, we established that on April 12, 2020, the village residents participated in the funeral and had contact with the confirmed case of COVID-19. During the epidemiological investigation, we identified 143 contacts, including 36 close contacts. Between April 28 and 29, 13 of the
Table 1 - Demographic Characteristics of COVID-19 Confirmed Cases, Mangistau region, Kazakhstan, June 2020

\begin{tabular}{|l|c|c|}
\hline \multicolumn{1}{|c|}{ Characteristics } & $\begin{array}{c}\text { Cases } \\
(\mathrm{n}=343)\end{array}$ & $\begin{array}{c}\text { Percent } \\
(\%)\end{array}$ \\
\hline$<14$ & & $14,3 \%$ \\
\hline $15-19$ & 23 & $6,7 \%$ \\
\hline $20-29$ & 74 & $21,6 \%$ \\
\hline $30-39$ & 69 & $20,1 \%$ \\
\hline $40-49$ & 45 & $13,1 \%$ \\
\hline $50-59$ & 55 & $16,0 \%$ \\
\hline$>60$ & 28 & $8,2 \%$ \\
\hline Occupation & & \\
\hline No occupation & 58 & $16,9 \%$ \\
\hline TCO workers & 35 & $10,2 \%$ \\
\hline $\begin{array}{l}\text { Workers of other } \\
\text { industrial enterprises }\end{array}$ & 59 & $17,2 \%$ \\
\hline Students & 15 & $4,4 \%$ \\
\hline Medical workers & 36 & $10,5 \%$ \\
\hline Military personnel & 11 & $3,2 \%$ \\
\hline School workers & 9 & $2,6 \%$ \\
\hline Civil servants & 7 & $2,0 \%$ \\
\hline Catering workers & 8 & $2,3 \%$ \\
\hline Retirees & 25 & $7,3 \%$ \\
\hline Police officers & 6 & $1,7 \%$ \\
\hline School children & 33 & $9,6 \%$ \\
\hline Other children & 17 & $5,0 \%$ \\
\hline Others & 24 & $7,0 \%$ \\
\hline
\end{tabular}

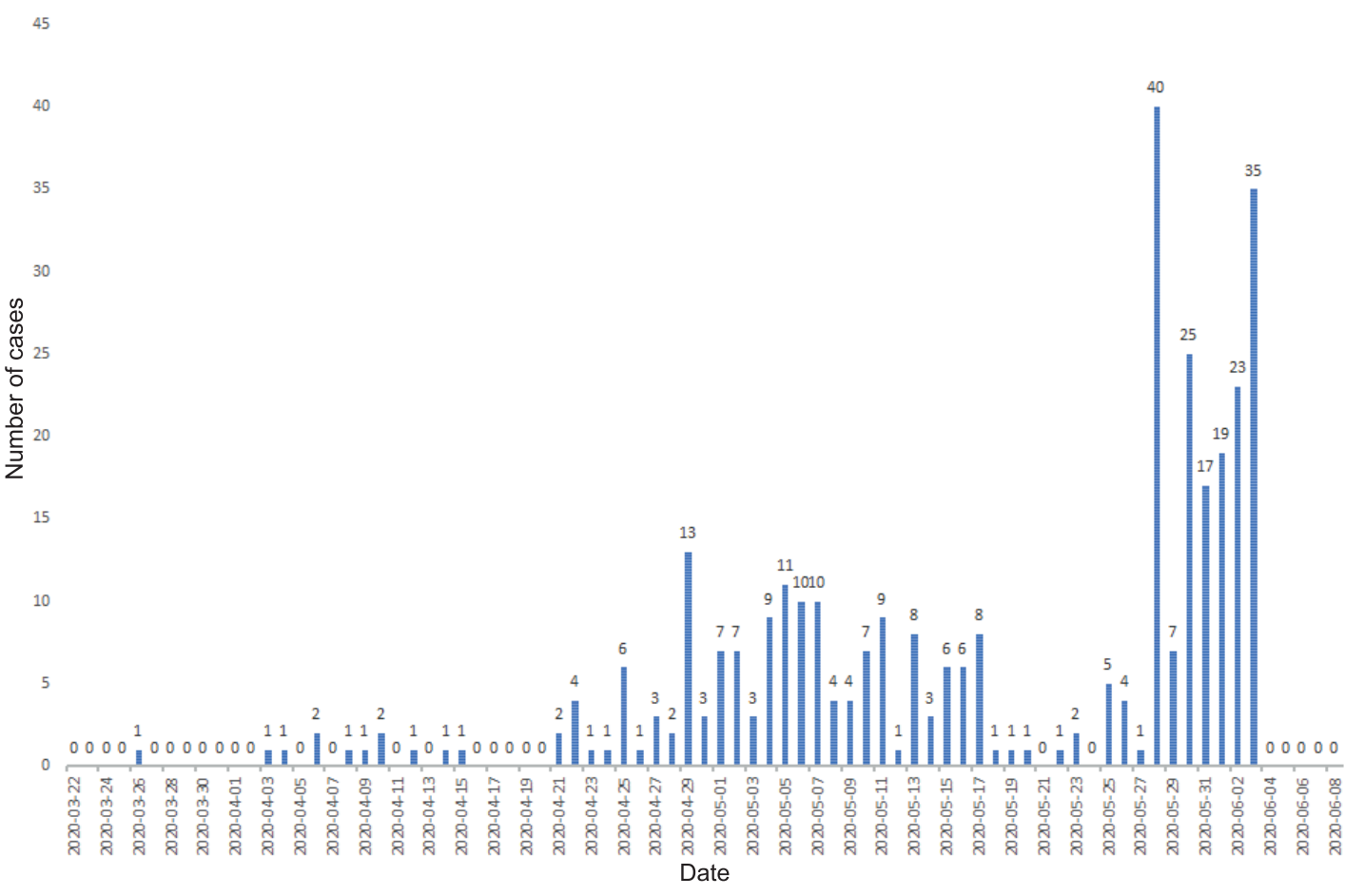

Figure 2 - Daily timeline of the COVID-19 in Mangistau region, March - June, 2020 
contacts were ill with COVID-19, including two cases in the city of Zhanaozen and 11 cases in the village of Senek.

Outbreak 2. The village of Beineu (May 4-17, Beineuskiy districts)

The index case was a local nurse in the village of Beineu. She was registered as a confirmed case on May 6, 2020 and had 49 contacts. Six of them showed positive results on COVID-19. From May 8 to May 11, 2020, when examining 88 people who had contact with these six patients, another 22 cases of COVID-19 were revealed. Subsequently, in the village we identified a total of 40 patients. Of these, $18(45 \%)$ were medical workers, who subsequently became a source of infection for $26(65 \%)$ patients with COVID-19. One woman, a medical worker, had contact with the index case at home, and then, from April 6 to May 4, 2020, she took part in the duty at the checkpoint where employees of the Tengiz oil field arrived, which subsequently became ill with COVID-19.

Outbreak 3. The village of Borankul (May 6-20, Beineuskiy districts)

The index case was registered on May 6, 2020. We identified 10 contact persons, of which two were his relatives and two contacts at work. Among the contacts, four had a positive test for COVID-19. On May 7, 2020, another case was registered, which had contact with 23 persons, among whom seven COVID-19 cases were identified. The next patient was identified on May 15, 2020 among workers who arrived from the Tengiz oil field. A total of 24 cases of COVID-19 were identified in the village. It should be noted that 20 of 24 patients were identified during the examination of a provisional hospital. Of the total number of cases, clinical symptoms were present in only 10 patients.

Outbreaks 4 and 5 Kalamkas and Zhetibay oil fields (15 May - 06 June, Mangistau districts)

Index case, resident of Aqtau. At the Kalamkas field, he worked in the Capital Construction Department. From May 15, 2020, she was in the rotational camp. During work in the period from May 24 to May 25, 2020, the case developed catarrhal manifestations (sore throat, mild cough). Self-medicated, she did not seek medical help. The case was identified and isolated only on May 29, 2020 after a work day during a medical examination (thermometry); the diagnosis of COVID-19 was confirmed by PCR. Were identified her contacts (171 employees); in 17 cases COVID-19 was diagnosed. Due to the free movement of workers between camps, an outbreak was subsequently recorded at the Zhetibay field.

\section{REFERENCES}

1 Shi Y, Wang G, Cai X-P, et al. An overview of COVID-19. $J$ Zhejiang Univ-Sci B (Biomed Biotechnol). 2020;21(5):343-360. DOI: $10.1631 /$ jzus.B2000083

2 Ahn D-G, Shin H-J, Kim M-H, et al. Current status of epidemiology, diagnosis, therapeutics, and vaccines for novel coronavirus disease 2019 (COVID-19). J. Microbiol. Biotechnol. 2020;30(3):313324. DOI: $10.4014 / \mathrm{jmb} .2003 .03011$

3 Malik YA. Properties of coronavirus and SARS-CoV-2. Malays J Pathol. 2020;42(1):3-11

4 Lai CC, Wang C-Y, Wang Ya-H, et al. Global epidemiology

\section{DISCUSSION}

The main reason for the spread of the disease was overcrowding and cross-contact between oilfield workers, which influenced the registration of outbreaks among workers in field camps. The active movement of workers between camps, the involvement of medical workers with no experience in using PPE to work at checkpoints and local hospitals, as well as the presence of a confirmed case of COVID-19 at funerals where participants did not use respiratory protection also influenced the spread of infection.

\section{CONCLUSIONS}

This article describes the epidemiologic features of the outbreak series in five settlements located in the oil production zone of Mangistau region of Kazakhstan during May - June of 2020. An exponential increase in numbers of COVID-19 patients in Beyneu districts appeared to be caused by exposure among the members of in canteens and dormitories for shift workers in oil-producing areas with the additional communityand hospital-transmission.

\section{Research transparency}

Research did not have a sponsorship. The authors are absolutely responsible for presenting the release script for publication.

Declaration about financial and other relations

The authors did not get the honorary for the article.

\section{Author Contributions}

Marat Syzdykov, Andrey Kuznetsov - conception and design of the work.

Marat Syzdykov, Lyudmila Byurabekova, Nurkan Sadvakasov, Andrey Kuznetsov, Svetlana Daulbayeva - acquisition, analysis of data.

Andrey Kuznetsov - drafting the work, preparation of illustrations.

Lyudmila Byurabekova, Toktassyn Yerubayev - revising and providing the final approval and finalization of the work.

\section{Ethics statement}

This study was a part of the routine work of the Ministry of Health of the Republic of Kazakhstan to provide methodological and practical assistance to local health authorities in organizing and conducting anti-epidemic measures for coronavirus infection in Mangistau oblast (province). Therefore, institutional review and informed consent were not required for this study. All data analyzed were anonymized.

of coronavirus disease 2019 (COVID-19): disease incidence, daily cumulative index, mortality, and their association with country healthcare resources and economic status. Int. J. Antimicrob. Agents. 2020;55(4):105946. DOI: 10.1016/j.jjantimicag.2020.105946

5 Maukayeva S, Karimova S. Epidemiologic Character of COVID-19 in Kazakhstan: A Preliminary Report. North Clin Istanb. 2020;7(3):210-213. DOI: 10.14744/nci.2020.62443

6 Semenova Yu, Glushkova N, Pivina L, et al. Epidemiological characteristics and forecast of COVID-19 outbreak in the republic of Kazakhstan. J Korean Med Sci 2020;35(24):e227. DOI: 10.3346/ jkms.2020.35.e227 